creasing of wool fabrics at the same time as it conferred shrink-resistance. Combined in the one process, these effects would enable development of easy-care tropical worsted fabrics. For a given weight of polymer, the optimum benefits in both shrink-resistance and abrasionresistance would be obtained only if the resin were polymerized by a method which at the same time anchored it chemically to the fibres.

Prof. Speakman suggested that cross-linking had the greatest potential as a shrinkproofing technique. No industrial process of this type had been developed, and this was due to lack of knowledge of the distribution of the reactive sido-chains in keratin. Moreover, in past investigations insufficient attention had boen given to the ratio of the amount of cross-linking reagent to the amount of wool. Unless this was strictly controlled, optimum cross-linking might not be obtained. If these problems were overcome, a process could be developed which would bo satisfactory for all end-uses except those requiring crease-resistance.

Dr. E. F. Denby and Dr. M. W. Andrews (C.S.I.R.O.) reported progress in analysing fibre movement during washing of untreated fabric and fabric shrinkproofed with the C.S.I.R.O. potassium permanganate/saturated sodium chloride process. They claimed that the direct effect of washing was fibre movement and showed that the treatment caused a reduction in the rate of fibre movement. For a given level of treatment this rate was constant up to at least 10 per cent linear shrinkage. Thus there was considerable fibre movement during the induction period (the period at the commencement of washing when no shrinkage occurs). The relation between shrinkage and the average fibre movement was independent of the level of the treatment. This indicated that the mechanism of felting was the same in the treated and untreated fabrics.

The force required to move the fibres during washing depended on their elastic properties, their frictional properties and the distribution and pressure of inter-fibre contacts. Average values of this force were obtained by pulling fibres from the fabric in the against-scale and withscale directions. The against-scale force for the treated fabric was considerably less than the value for the untreated fabric, whereas the with-scale force was only slightly altered by the treatment. The force was also altered by washing the fabric. A significant increase in the against-scale force occurred during the induction period. It was suggested that this increase was due to changes in the surface of the fibres brought about by the mechanical effect of the washing, and that an increase in the with-scale force, which was observed at the end of the induction period, might be associated with the formation of 'entanglements' of the type suggested by Shorter.

Developments and progress in shrinkproofing were reviewed by Dr. J. R. McPhee (C.S.I.R.O.). He suggested that research into the chemical degradation methods should be directed towards making simpler and cheaper processes, keoping in mind the disadvantages that still existed in processes of this bype. Although resin treatments appeared to offer genuine advantages, these advantages tendad to be outweighed in practice because the cost and complexity were high. The most promising was the formation of polyamides on the fibre surface by $a$ technique called 'intorfacial polymerization'.

The informal discussion prriod was led by Prof. A. Datyner (University of Now South Wales) and Dr. A. J. Farnworth (Australian Wool Bureau), who briefly discussed problems and anomalies encountered in shrinkproofing research. The main impression gained from this discussion period was of wide gaps in basic knowledge. At present many phenomena have not been explained, and in some cases sound basic ideas have not beon devoloped to the stage required for industrial use. Dr. Farnworth listed soveral instances; for example, the efficiency of the simple oxidation processes would be considerably increased if the reaction could be restricted entirely to those chemical sites the modification of which is essential for changes in the frictional properties of the fibres; however, little is known about these sites. Delegates reported that the effoct of surface contaminants on the efficiency of many processes is not fully understood; nor did they know how to explain the pattern in which $p H$, temperature, otc., of the felting media affect felting rates. Above all, there is very little information about what happens physically in a fabric during felting.

To conclude on this note would be to deny the sound progress made in this field. The manufacturer has now come to a realistic appreciation of the need for careful quality control. Dr. MePhee reported that there are at least six processes in common use producing good results for a wide variety of applications; several of thoso processes do not impair the 'handle' of the wool. Thus the textile chemist has disdained the luxury of inactively waiting for basic research to point the way to the process ne plus ultra.

E. F. DENBY

M. W. ANDREWS

\title{
ENERGY AND THE EUROPEAN ECONOMIC COMMUNITY
}

\begin{abstract}
A BROADSHEET written by J. Hartshorn, entitled An Energy Policy for E.E.C., and issued by Political and Economic Planning*, reviews briefly the national energy policies of Belgium, France, Western Germany, Italy, Luxembourg, the Netherlands and the United Kingdom, the search of the European Economic Community for a co-ordinated energy policy up to the 1962 proposals for a common market in energy, and finally considers the prospects for a policy.

While during the past three years the concepts on which a logical and coherent policy might be based have been steadily refined, there is no certainty that the member nations can be brought to accept one. Nobody, even coal interests, expects to be able to expand domestic fuel-producing capacity and productivity enough to keep pace with the growth of energy requirements to the extent that, for example, European farm interests can con-
\end{abstract}

* Planning, Vol, 29. No. 469 (18th March, 1963). An Energy Policy for E.E.C. By Jack Hartshorn. Pp. 55-98. (London: Political and Economic fidently be hoped to expand in domestic farm products. Energy demand per head shows less sign of levelling off within rising standards of living than food demand does.

The French have some objections of principle to the concept of an open common market in energy, and are not convinced that this is the surest way of arriving at the lowest energy costs if that means giving the nonEuropean oil companies free play at a time when the Community's energy resources are on the point of being used up. Reliance on the diversification of sources of oil supply is a real safeguard, but its importanco can be exaggerated. Diversification may raise the question of possible preference to particular oil-producing areas. In the context of scarcity, the 4-6 month level of supplies suggested for stocks by the European Economic Community has much logic, but may not be cheap even if it supplies sufficient insurance against the interruption of Soviet supplies as well.

Apart from the vested interests of the European nations concerned, Mr. Hartshorn sees cogent arguments for delay, and points out that it is difficult not to share some 
of the reservations of the Governments asked to commit themselves to these oil policies. An oil policy for Europe fitting the provisions of the Treaty of Rome and a coal policy fitting a possibly revised Treaty of Paris could exist, but he hesitates to suggest that this will be the outcome. What is remarkable, moreover, is the almost complete absence in the Broadsheet of any reference to nuclear energy.

\section{PETROLEUM IN 1975}

$\mathrm{O}$ N April 27, 1963, Esso Petroloum Co., Ltd., celebrated its seventy-fifth anniversary and a special issue of the Esso Magazine was published to mark this milestone in the Company's history.

The leading article, entitled "A Look Ahead to 1975", makes some interesting forecasts for the petroleum industry in Britain. If world economic progress during the next twelve years continues at the same rate as in the past twelve years, it is estimated that world oil demand will rise from the 1962 figure of 1,200 million tons to 2,200 million tons in 1975; in Britain the demand will approximately double the 1962 figure of 52 million tons to 102 million tons by 1975. New sources of oil may stem from the discovery of large natural gas deposits in Holland in 1961 and this has inspired an under-water search for oil off the British coast in the North Sea, a joint venture by Esso, Shell and British Petroleum. Esso is at present exploring possibilities in Kent, Sussex and Hampshire.

In the matter of transporting crude oil from overseas to refineries in Britain, tankers of 26,000 tons d.w. were among the largest afloat in the 1950's; now 80,000-ton tankers are already a feature of the Esso fleet and an 86,000 -ton ship is scheduled for service early next year. The economic advantages of tankers up to 150,000 tons d.w. are at present under consideration, and the possibility of nuclear-powered tankers being used by 1975 is by no means remote.
If the forecast of demand for petroleum products doubling itself in the next twelve years is correct, then Britain's refining capacity will have to be increased to take care of at least another 50 million tons of oil by 1975 , involving a capital outlay in the region of $£ 200$ million. In the distribution of refined products, pipe-lines are destined to play an increasingly important part in the years ahead; it is estimated that by 1975 about two. thirds of the 'white' products marketed by Esso alone in south-east England and the Midlands will travel by pipe-lines.

Fuels for engines of all kinds, ships' bunkers, cars, lorries, locomotives, aviation fuels, etc., are expected to increase the demand by 75 per cent, oils for heating about 70 per cent greater in 1975 than in 1962 . Regarding heavy oils for industry, apart from traditional fuels, now methods of generating electricity are anticipated by 1975 , such as magnetohydrodynamics, which converts the energy into hot gases, produced by burning fuel, directly into electricity in a strong magnetic field; the fuel cell would convert petroleum products into energy at a much higher efficiency than 45 per cent, the maximum efficiency that at present is achieved in the modern power station. Finally, the capital expenditure in Britain to cover all these developments in the oil industry is anticipated to be more than $£ 1,000$ million during the next twelve years.

H. B. MILNER

\section{PRE-FLUVIAL, AUTOGEOSYNCLINAL SEDIMENTATION IN THE NAMURIAN OF THE SOUTHERN CENTRAL PROVINCE}

By B. K. HOLDSWORTH

Department of Geology, University of Keele

$S^{\mathrm{I}}$ INCE the publication of Gilligan's ${ }^{1}$ now classic study, British stratigraphers have stressed the deltaic and terrestrial aspect of Namurian rocks developed in the Central Province of England-'The Millstone Grit Series'.

While coarse, cross-bedded arkosic sandstones-the 'fluvial grit facies' of Trotter ${ }^{2}$ - such as those investigated by Gilligan undoubtedly record terrestrial, fluvial activity (cf. ref. 3) and represent an important stage in the evolution of the Central Province, it has long been realized that in the south of the Province a complex history of Upper Carboniferous sedimentation preceded the first appearance of fluvial conditions ${ }^{4-6}$. An important newly published account of Carboniferous rocks in the Ashover district ${ }^{7}$ together with earlier work in the StaffordshireDerbyshire region and recent investigations in north Staffordshire and south-west Derbyshire allows the period between the close of the Dinantian and the first establishment of fluvial environments in the region to be seen in clearer perspective.

Hudson and Cotton ${ }^{8}$ stressed that Dinantian successions in the area are of two contrasting aspects-'basin' and 'massif'. The sedimentation contrast was apparently related to a northerly projection of the Carboniferous Central Land Barrier (St. George's Land). On the submerged surface of this projection from the ancient block developed the limestones of 'massif facies'. To the north and west lay the basin area.

During $D 1(B 2)$ time a part of the western and northern margin of the block projection in Derbyshire became marked by a line of limestone-reef building activity. To-day the belt of 'reef-knolls' is almost completely exposed from the upper Dove Valley to the Castleton district. East and south of the belt in Derbyshire, backreef, massif limestones are exposed (cf. refs. 9 and 10). West and north of the belt, in north Staffordshire and north Derbyshire respectively, borings show contemporaneous limestones and shales of basin aspect ${ }^{8}$.

A slight increase in differential movement between the geotropically negative basin- and positive massif-areas probably explains the $D 1(B 2)$ reef-building episode and it appears that this movement continued into $D 2$ times. By late $P$ time, however, the positive tendency of the massif projection appears to have been lost and rather similar, relatively argillaceous limestones accumulated over earlier basin- and earlier massif-areas alike ${ }^{8}$.

The framework which was to govern tho distribution of sediment accumulation during some two-thirds of Namurian time now developed, probably in late $P$ time, through recrudescence of differential movement between basin- and massif-regions. Uplift along the earlier reefbuilding line resulted in an essentially monoclinal fold. Erosion exposed the line of $D I(B 2)$ knolls and gave rise to the local $D 1(B 2)-E 2$ (Namurian) unconformity at the massif margin in north Derbyshire ${ }^{11}$ and the upper Dove Valley $^{8}$.

The re-establishment of a positive tendency in the massif exerted a profound control on Namurian sediment accumulation. Contrast between thick earlier Namurian 